\title{
G
}

COUNTERFUTURES

Left thought \& practice Aotearoa

FIVE

2018 


\section{Editorial: Shock and care}

\section{Tim Corballis}

HUNDRED YEARS AGO, European avant garde artists
delighted in charging into sacred spaces and smash-
ing them up. They celebrated the stray bullets that
destroyed the art treasures of another century: 'We greet with
pleasure the fact that bullets whiz into the galleries and palac-
es, into the masterpieces of Rubens, instead of into the homes of
the poor in the workers' districts', wrote George Grosz and John
Heartfield. ${ }^{1}$ They pitted themselves against a bourgeoisie that
could happily look away from bloodshed and burning cities while
holding dear this or that old painting.
The avant garde set one kind of art against another:
an art of shock and challenge and life against an art that pre-
sented and preserved ideals of beauty that were found only in

1 Cited in Brigid Doherty, 'The Work of Art and the Problem of Politics in Berlin Dada,' October 102 (2003): 74. 
frames, and nowhere outside the gallery. Their art had something in common with storming the Bastille or overthrowing the clergy. If the gallery was a place of meaning and beauty, why was it in there, pictured and distant, and not out here, in the lives of the people?

Why am I telling this story? There are a few reasons. First, it is one of the origin stories of the contemporary art gallery. Avant garde art-including elements of Dada and Cubism, urinals in galleries, newspapers stuck to canvas, and the deconstruction of easily recognisable 'scenes' in painting-aimed to break us out from a removed contemplation and into everyday life. Much of the history of Western art since then has been about the same thing. It has put more and more 'ordinary' objects in galleries, insisting that they are as valuable as any Old Master; it has put more and more art out in the street and the field; it has insisted that bodies and performances and actions and conversations are art. In many different ways, even if art has often remained quiet and removed and ineffective, and life has often remained devoid of beauty and meaning, the avant garde project of crossing the boundary between art and life has continued.

Second, the avant garde project remains a touchstone, not just for contemporary art, but for my own thinking about art and politics. This personal attachment is the product of some nostalgia and Eurocentrism on my part, and undoubtedly produces a story of the avant garde that isn't even terribly accurate. Having admitted a certain personal attachment to an image of what art might look like, the third reason I begin with this story has to do with the questions it raises: questions about art and politics, about revolt and shock and transgression, about the values of care and respect that get lost in the midst of more violent virtues, and about its particular historical context as well as other contexts, cultures, and values. So even if it's an old, inaccurate, and Eurocentric story, it's a good story because it can take us a long way from itself. 
In making an equation between the artistic act and the revolutionary one, the big question this story raises is to do with the relationship between art and politics. At other times, I have wondered whether they are perhaps opposites-whether the question is as simple as this: what to do, art or politics? Often, the decision to do one can seem like a decision not to do the other. In my case, the decision to write a novel can seem like the decision to remove myself from the world, to hide away in a quiet corner and forget the struggle. The big question therefore becomes a small question too, one that keeps recurring: what to do, now, today, art or politics?

I know that there are plenty of reasons to think we can do both: have the cake of art and, in the act of being political, eat it too. I know that art is a place where people are represented in various ways - as artists, or as characters or people in books, photos, and films - or excluded altogether. It is a place where the choices to include or exclude matter very much. And I know that art is political because political action always needs its art-its posters and placards, its puppets and masks, its costumes and performances.

But still, like the old artists' joke — what to buy, drugs or art supplies? - it raises the question of the allocation of resources. Is it really a good idea to spend all that time writing, when there is exploitation and oppression in the world?

I think one of the quickest and easiest ways of saying that art is political is to put art in the service of politics. Placards and street theatre are there to make a point, and gallery installations, participatory art projects, novels, and plays all engage with this or that wider issue and justify themselves in the process. Even if some artists balk at the suggestion of 'art in the service of. . .', art's writing in blurbs and reviews, or gallery walls, often makes the connection nonetheless. A cursory glance at exhibition 
writing will see curators raise the question, perhaps defensively, of art's social and political significance.

However, if we can only imagine art in the service of politics, then any end of politics we envisage also means the end of art. I hope that, in our political actions, we are imagining something, some better world where we or our children can rest a little after the struggle, at least until the next injustice is tackled. But if art only ever serves politics, then to imagine a better world where we can set aside the struggle is to imagine an artless place, a dead utopia where we forget theatre and only till the fields.

What of the other possibility? What about putting politics, instead, in the service of art? To think about the big question of art and politics is to think about the meaning of what we do. Art can be a way to withdraw from the busy activist worldindeed, I think it often requires some kind of withdrawal, to ponder and plot and imagine-but it can also be a reminder of what sort of world we might be aiming for. To ask, even if only as a thought experiment, what art will look like after the revolution, is to ask about what life will be like, or what life should be like; it is to ask about what kind of world we hope to build.

There is a potential conflict between forgetting the actual world with all its urgent tasks (Blockade! Strike! Boycott!) and forgetting the future world that we desire. The story of the European avant garde is a story about this conflict, this tension. It is a story in which the urgent tasks are all outside the gallery, but the future hope and promise are found inside it. The reason the avant garde artists are still artists and not just activists (or philistines) is that they still believe in what is there in the gallery, even as they break in and destroy it. They believe in stealing whatever beauty is there on the canvas and making it real in the world. They believe that something good is trapped inside those gilded frames. The desire to destroy art and preserve it 
simultaneously is confusing and complex. That is the reason why this story is the foundation of so many different and contradictory ideas and movements, some of which still want to hold on to galleries and preserve them from harm, even as they try to revolutionise art itself.

Reflecting on this story is a way to keep thinking about art and politics. It is a way to think about the point of it all.

* $\quad * \quad *$

Of course, it is a story from another time and place. The idea of shock, of challenging the status quo, has its historical context, and it has a particular opponent. Its distance from us can be useful if it can make us think about the value of shock and transgression in our own time. It is one thing to shock the European bourgeoisie of the early $20^{\text {th }}$ Century-but who, now, needs shocking?

There is a danger of just repeating an avant garde manoeuvre outside of the context of its historical birthplace. Cassandra Barnett gets at that question in her contribution to this issue-she writes about contemporary artists in Aotearoa, such as Luke Willis Thompson, who have come under fire for 'opening new wounds', especially for Māori and Pasifika communities. These communities might not be the target of Thompson's attempts to shock, but the danger is there nonetheless. His film works on show recently at the Adam Art Gallery, for example, are large, moving-image portraits showing the faces of people who, in different ways, have some relationship to war and the violence done to people of colour, including descendants and partners of those killed by police in Britain and the United States. This might be uncomfortable for an art audience-although art audiences should, by now, be used to discomfort_raising all the old questions about what cameras do to a black face and how they might be complicit in violence. But even while Thompson's 
work raises the question, it continues to perpetrate that violence, poking around in those wounds in the process of exposing them for the sake of art. If there is a place for the discomfort and trouble caused for the stereotypical gallery visitor, what of the other kinds of trouble caused-and visible on the subjects' faces in his film works-for the communities that Thomson enters with his camera? His work is certainly all about making his audience uncomfortable. But there is a failure of care in forcing his subjects and their communities into the same objectified roles he is, I think, hoping to address.

The larger point here is not to single out Thompson, but to ask questions about how we navigate attitudes of shock and care. These are not only questions for art, but for politics too. And I should emphasise that I don't want to take sides either way. I believe in shock, and I believe in care, and I believe in thinking hard about the world in order to work out where each should be applied. ${ }^{2}$

I know the way I have been talking about art and politics is too grand. Even the words 'art' and 'politics' are too big; they hide a lot of very different, very specific practices under their clumsy umbrellas. But these big thoughts might help make sense of some of those particular practices and situations. For me, they help to make sense of depression, the depression of thinking it's

2 It is of current relevance that feminism is caught in similar arguments about shock and care. They are arguments about whether sex is a place of male violence against women, or whether it is a shocking, transgressive thing that breaks down patriarchies and binaries. American feminist Catharine MacKinnon, for example, placed her hope in legal protection for women against men's sexual violenceand something of the same spirit is there in the protections offered by Women's Refuges and other safe spaces. Eileen Willis and others subsequently criticised MacKinnon's position (without, of course, wishing to shut down the refuges) as prudish and conservative, denying the power of transgressive desires, including even the most shocking kinds: desires for pain and violence. Again, we can think of these questions in terms of the particular opponents they imagine: the violent, objectifying man who uses sexual violence for power on the one hand; or, on the other, the upstanding family patriarch who denies women their pleasure. 
all too hard and the world is too fucked up. The very ordinary depression of the worker, the depression of the not-so-tireless activist, the depression of the parent, the depression of anyone whose joy and meaning have been erased in the act of some endless, necessary task. At the same time as questions about art and politics make sense of depression, they also make sense of motivation, which is perhaps depression's opposite. Where are we headed? Why are we headed there? Why do we put so much effort into our political campaign? What is the point? Art doesn't answer those questions once and for all. But maybe art is a word that we can reach for when we wonder what the point is; and it might be that, reaching for art, we also reach for all the arts, the visions that all cultures have to offer.

It might be that the avant garde story exaggerates the artlessness of the world outside the gallery. After all, people everywhere have always decorated their homes and their bodies. They have always engaged in aesthetic activity of one kind or another and found meaning in ritual. This is the lesson of the academic discipline of cultural studies, which has influenced much of the social sciences: the idea that working people are not just caught in the meaningless drudgery of the workplace but have their own cultures that can be understood and celebrated.

Is ordinary life a matter of meaningless drudgery, something to be saved by an injection of art's beauty, or is it already filled with the meanings people make for themselves? It is another place where I prefer not to take sides. It is worth thinking about what particular lives are meaningless, or what particular aspects of lives, and what our art and political action can do about that. Meanings and cultures are found in all kinds of places; and still, in others, lives lose their meanings-so meanings are still something to struggle over, and politics is still concerned with art just as much as art is concerned with politics. 


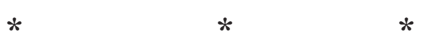

For this issue, we were interested in eliciting some thoughts about the art and the Left. My own thoughts start with that old European story, but we also wanted other perspectives and starting points. For that reason, I wrote a quick provocation for a number of artists and writers to respond to, in thinking about how art relates to politics:

Should we learn something from art? Should art shock—and if so, who should it shock? Does art express anger or pain? Does it contain hints of utopian vision? How does art relate to the arts?

How do Indigenous arts and theories of art relate to the Left? Is 'activist/educational art' simply the replacement of art by education/activism? Would that simply be the loss of 'expert' art and 'aesthetics', or would it be the loss of art altogether? Would it matter either way?

How do specific art forms and practices relate to the Left in Aotearoa: whakairo, Dada, land art, folk arts, craft, taonga pūoro, architecture, design, video art, storytelling. . .take your pick. How does art relate to its audience and/or community?

This was intended as a prompt and a starting point. I wanted a prompt that was as inclusive as possible-and no doubt it could be more inclusive-but I also wanted words like 'shock' and 'utopia', words that suggest impatience with the established truth of what is. We were, though, ultimately as open to the particular observation as the large, programmatic statement. The pieces in this issue by Matariki Williams, Amy Howden-Chapman, Fiona Jack, and Cassandra Barnett came out of that conversation. We also conducted an interview with the Mata Aho artist collective, 
and commissioned a zine by Bryce Galloway, artist and author of Incredibly Hot Sex with Hideous People. This set of writing is only a small part of a larger and longer conversation that I would love to see continue. One thing that struck me, as our various writers struggled with complex material, is how big and difficult a conversation it can be-so many different interests and ideas are at stake, ideas that reach from the concrete across to the abstract and speculative. The writing here deals with art, but as it does so it also deals with the political representation and visibility of Māori and women, with environmental issues, and with the overlap and conflict between Left and Māori goals and worldviews. I hope it can be read as part of a wider conversation about how big questions and local concerns might be combined. That, I think, can be one of the virtues of doing and talking about art. 
If you like what you have read, please subscribe or donate.

\author{
G \\ COUNTERF UTURES \\ Left thought \& practice Aotearoa \\ (C) Copyright Counterfutures 2018
}

